\title{
STATUS OF THE SCARLET TANAGER \\ IN SASKATCHEWAN
}

\author{
by Margaret Belcher, Regina
}

Perhaps no bird in Saskatchewan has been observed and reported more often without being officially recognized than the Scarlet Tanager (Piranga olivacea). Ordinarily, a species is given only hypothetical status on the provincial list until a photograph or, preferably, a specimen establishes its occurrence. In the absence of these two forms of evidence the Scarlet Tanager remains a hypothetical species on the Field check-list of Saskatchewan birds (4th ed. Revised June, 1959. Stuart Houston, Fred G. Bard and Robert W. Nero). Yet the many observations of this conspicuous bird by experienced observers through the years suggest that the Scarlet Tanager should be given full status.

The breeding range of the Scarlet Tanager as given by the A.O.U. Check-list of North American birds (1957) includes eastern North Dakota (Fargo, Grafton) and southeastern Manitoba (Winnipeg, Indian Bay), and it is described in the Check-list as accidental or casual in Saskatchewan (Indian Head).

References to the Scarlet Tanager in Saskatchewan go back to the end of the last century. When Seton (1886) was describing the range of the bird in Manitoba, he added the note "rare at Qu'Appelle", and subsequently (1891) he attributed this information to Guernsey, an early naturalist resident in the area. Again, in Macoun (1900) the Scarlet Tanager is described (on the strength of Seton's statements) as "seen as far west as Qu'Appelle in eastern Assiniboia".

At Indian Head, the Scarlet Tanager was reported by George Lang in May, 1891; Mitchell (1924) quotes from Lang's letter, "Harvey found one dead after a snowstorm in late May, 1891, at Indian Head, which he mounted." J. Alden Loring of the U.S. Biological Survey listed the species in a report of field studies at Indian Head from June 19 to July 10, 1895 (unpublished field notes now in the file of the U.S. Fish and Wildlife Service). His report reads simply: "One heard. A specimen was seen that had been found dead in the vicinity." Loring does not say that the specimen was a recent bird; it may well have been the bird found dead in the district in 1891, reported by Lang. Again on May 22, 1908 a Scarlet Tanager was reported seen at Indian Head by George Lang (In Annual Report of the Department of Agriculture of the Province of Saskatchewan, 1908).

Mitchell (1924) also noted the Scarlet Tanager as "reported seen at Estevan and Moose Mountain", and a note in the Saskatchewan Museum of Natural History files adds the comment "reported as seen occasionally at Carlyle by Mr. Roe (Ranger)." These latter observations are given without date or other supporting data, but they are of interest because this is the part of the province in which we should expect the Scarlet Tanager. On July 19, 1956 George Blanchard reported seeing two males and one female in the Moose Mountain Provincial Park (Blue Jay 14:119), and in June, 1959, when the Saskatchewan Natural History Society summer meeting was held in the Park, an observation of a Scarlet Tanager was again reported (Blue Jay, 17:132). On the latter occasion, the bird, a male, was first seen by Mrs. A. G. Lawrence, and its identification was confirmed by A. G. Lawrence and E. Manley Callin. I wrote to Manley Callin for further particulars of this sighting, and he replied as follows (letter of June 23, 1965) :

"I remember the details as if it were yesterday and I can still 'see' the bird and the setting. The meet was held June 12-14 and the date of observation would be June 13 as we were in a cavalcade of cars and nearing Jabe Lake where the entire group had noon lunch. Mr. and Mrs. Lawrence were riding in my car and we were moving along leisurely at the very end of the line. Suddenly Mrs. Lawrence said in a very excited and breathless manner, 'Oh Manley, look!' Looking in the direction she pointed I saw a male Scarlet Tanager (my first) perched on the tip of a shrub not many yards ahead of the car and 
to our left. I brought the car to a sudden stop almost abreast of the bird and fortunately, it did not fly immediately. Conditions of observation could not have been better. The bird was in plain view about 15 feet off the roadway and probably about 30 feet from the car, and not a twig or leaf marred our view. All essential details could be clearly noted and seeing this scarlet and black bird against the back-drop of tall, green trees lining the roadway was quite startling and is a scene I shall never forget. All three observers were quite spellbound and who can measure time under such circumstances? Certainly the bird did not linger and I would guess that it sat quietly for only about 10 or 15 seconds before flying off into the trees. Both of the Lawrences had seen the Scarlet Tanager on at least one previous occasion in Manitoba but, as you can imagine, it was still a big thrill to them." This record has special validity, representing the careful observation of two experienced and well known observers, Manley Callin and A. G. Lawrence.

Three other localities in eastern Saskatchewan have reported observations of the Scarlet Tanager in recent times - Fort Qu'Appelle, Rocanville, and Yorkton. A male was noted on May 21, 1950 at York Lake, four miles southwest of Yorkton, by Nancy Morrison and seen later that day by Henry Beck and on the following day by Stuart Houston and Mary Belcher. It was very tame and allowed observers to approach within 10 feet of it (Houston, 1950).

At Rocanville a male Scarlet Tanager was seen about seven miles northwest of the town (SW 13-17-32 w1) in June, 1956 and reported to the Blue Jay by Mrs. D. Sutton (Blue Jay, 14: 119). The particulars of the observation are worth recalling - both Mrs. Sutton and her eleven-year-old daughter, who first sighted the bird, were able to get very close to the bird when it flew to a branch about six feet from the ground on the exposed edge of a bluff. Mrs. Sutton's description of the bird in her letter to the Blue Jay supports her identification: "Plainly he was a male Scarlet Tanager in all his spring glory. The bright even red head and body contrasted sharply with clear cut, wholly black wings and tail. Complete absence of any yellow assured me it wasn't a Western Tanager and the red head eliminated any chance of him being an oriole. In size he was between a sparrow and a robin." Mrs. Sutton also recognized that the local stands of poplar interspersed with large oak trees and sprinkled with underbrush, in a favoured corner bordered by the Qu'Appelle River on the north and the Scissors Creek on the west, provided suitable habitat for this species.

The following year, 1957, Errol Cochrane of Fort Qu'Appelle reported to Manley Callin that he had seen a male and female Scarlet Tanager on June 3 in a nearby coulee. Callin visited the spot with him later that day and together they watched a bird which was almost certainly the female, but neither bird was seen again (pers. corres., June 23, 1965).

Further west, and therefore extending the range of observations of the Scarlet Tanager in Saskatchewan, there are sight records for both Regina and Moose Jaw. In 1940 or 1941 a male was seen by Dick and Ada Bird in willow brush at a slough northeast of Regina, but it was not reported at the time because the Birds did not think of it as rare, having just returned from Florida where Scarlet Tanagers were commonly seen (Belcher, 1961). On May 18, 1959 a female Scarlet Tanager was seen in Regina by George F. Ledingham, and later in the day by Frank Brazier and Elmer Fox (Belcher, 1961). Since then, I have heard on two occasions of birds seen in Regina by inexperienced observers, that were believed to be Scarlet Tanagers. At Moose Jaw a male Scarlet Tanager was seen by George F. Ledingham at his farm six miles west of the city on May 19, 1951 (Belcher, 1958).

At Young, some 100 miles northwest of Regina there is a record of a male Scarlet Tanager seen July 19, 1963. Charles F. Southey, who saw the bird, states that he had a very good look at it (pers. corres., January 19, 1964).

Salt and Wilk (1958) list the Scarlet Tanager as hypothetical for Alberta. However, on November 2, 1964 in Calgary, a female struck a window and died; this recent specimen provides the first authentic record of this species for Alberta (Myres, 1965). Meanwhile, the evi- 
dence of observations in Saskatchewan, assembled from the records with the help of E. Manley Callin, C. Stuart Houston and Robert W. Nero, would lead us to define the status of the species in this province as follows: uncommon summer visitant in the south, possibly even breeding in the extreme southeast. It would be most desirable to get a definite breeding record for the species in Saskatchewan.

\section{LITERATURE CITED}

A.O.U. Committee. 1957. Check-list of North American birds. 5 th ed. Baltimore.

Belcher, Margaret. 1958. Bird notes from a farm shelterbelt. Blue Jay, 16:101-104.
Belcher, Margaret. 1961. Birds of Regina. Special Publication No. 3, Sask. Nat. Hist. Society, Regina.

Houston, S. 1950. Scarlet Tanagers. Blue Jay, $8: 13$.

Macoun, J. 1900. Catalogue of Canadian birds. The Queen's Printer, Ottawa.

Mitchell, H. H. 1924. Birds of Saskatchewan. Can.Field-Nat., $38: 101-118$.

Myres, M. T., ed. 1965. Bulletin No. 35, Calgary Bird Club. Dept. of Biology, University of Alberta, Calgary. Mimeo.

Salt, W. R., and A. L. Wilk. 1958. The birds of Alberta. The Queen's Printer, Edmonton.

Seton, E. E. T. 1886. The birds of western Manitoba. Auk, $3: 324$.

Thompson, E. E. [E. E. T. Seton]. 1891. The birds of Manitoba. Proceedings of the U.S. Nat. Mus., $13: 457-643$. Washington, D.C.

\section{NOTE ON THE WESTERN TANAGER AT REGINA} by Hugh C. Smith, Regina

On May 12, 1965 I observed what I took to be a male Western Tanager (Piranga ludoviciana). The bird was seen flying about in the trees that line the square of the RCMP barracks in the city of Regina, and it drew my attention away from the Baltimore Orioles in the vicinity because of its vivid orange-red head which contrasted sharply with its yellow body and black wings. Because $I$ was on my way to work I was "unable to pursue the bird for any length of time. Once at work I telephoned my wife and gave her a verbal description of the bird I had seen. After consulting Peterson's Field guide to western birds, she confirmed my thoughts that it was a Western Tanager. She also advised that it was recorded as being in Saskatchewan in Peterson's guide and in the Field check-list of Saskatchewan birds, but that no mention of it was to be found in Belcher's Birds of Regina (1961). Here the matter rested until another observation of a male Western Tanager was brought to my attention.

On May 20, 1965, again at the RCMP barracks, a number of persons called my attention to a strange bird that was flying about the trees outside their office window. I was able to identify it as a male Western Tanager in spring plumage. On this occasion it was very carefully observed and was easily compared to the Baltimore Orioles with which it was associating. The next day I brought my Peterson's guide to work and showed the illustration of the Western Tana- ger to those who had seen the strange bird and they agreed that this was the bird that they had seen the day before. It is to be noted from the December 1964 issue of the Blue Jay (p. 155) that the previous early date for recording this species in Saskatchewan was May 13. These two observations could have been observations of the same bird, but because of the time difference between the two sightings I am inclined to think that two separate birds were observed.

Editor's Note: The Western Tanager is not listed in the Birds of Regina, but the reporting of Smith's 1965 observations makes this an appropriate time to refer to a sight record for Regina reported to the author just as the book was going to press. On June 1, 1961 Mrs. Helen Tobin saw a bird drinking at her bird bath on Angus Crescent which she believed to be a male Western Tanager, having known this species in the United States. There was no way of verifying this observation, since other observers were not able to locate the bird, and this isolated and unverified record was therefore not included in the Birds of Regina. The following year, 1962, a male Western Tanager was reported as seen by Marion Goudie on May 15, and on May 17 Mrs. Holly Wallace reported a second observation, describing the bird she saw to Frank Brazier as a brilliantly plumaged bird with yellow body, black wings and red head. Again, other observers who went to look for the bird were unable to find it. 